\title{
National Banks as Executors, Administrators and Trustees.
}

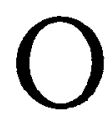

$N$ DECEMBER 23, I9r3, an act of Congress, popularly known as "The Federal Reserve Act," became a law. Under this act the Federal Reserve Board, created therein, is vested with certain powers. Among other things:

Sec. II. The Federal Reserve Board shall be authorized and empowered:

(k) to grant by special permit to national banks applying therefor, when not in contravention of state or local law, the right to act as trustee, executor, administrator or registrar of stocks and bonds under such rules and regulations as the said board may prescribe.

Whether or not the foregoing provision is constitutional has been the subject of legal discussion in every state in the United States.

The Supreme Court of the State of Illinois has already passed upon its constitutionality and determined it adversely." "There is. now pending in the Supreme Court of the State of Michigan a proceeding in which the constitutionality of the provision is involved $^{2}$ and similar suits have been and undoubtedly will be instituted in a number of other states.

It will be foreign to the purpose of this brief article to discuss any procedural matters in connection with the determination of the constitutionality of 'said section. It will rather be our purpose to discuss briefly the contentions being urged against its. constitutionality.

I.

Did Congress delegate a legislative power to the Federal Reserve Board? Unless it is concluded that Section II (k) of the Federal Reserve Act is not a delegation of legislative power

I People v. Brady (1915), 271 I11. 100, 110 N. E. 864.

2 Grant Fellows v. First National Bank of Bay City. 
to the Federal Reserve Board, then the discussion as to its consti-tutionality must end here.

The governnent of the United States is one of limited and enumerated powers. The power to make laws is vested in Congress $^{3}$ and it is now unquestionably established "that the power conferred upon the legislature to make laws cannot be delegated by that department to any other body or authority."

If the language in Section II (k) can only be construed to mean the vesting in the Federal Reserve Board the power "to grant" to national banks, in its discretion, according to its rules and regulations, the corporate power to accept and execute trusts of a certain character, when not in contravention of state laws, then, of course, this is a clear delegation of legislative powers to the Federal Reserve Board and the provision is void.

However, in examining a statute for the purpose of determining its validity, every intendinent is in support of its constitutionahity and it must be presumed to be constitutional unless its repugnancy to the constitution clearly appears. 5

While it may be conceded that Congress cannot delegate its power to make a law, it is establislied that it can "make a law to delegate a power to determine some fact or state of things upon which the law makes or intends to make its own action depend."

The delegation of power to make the law, which involves a discretion as to what it shall be, is not valid; but that which confers an authority or discretion as to its execution, to be exercised under and in pursuance of the law, is valid. With this dis-

3 U. S. Const., Art. 1, $\$ 1$.

4 Cooley, Constitutional Limitations, 7th Ed., p. 163; Field v. Clark (1892), 143 U. S. 649, 692, 12 Sup. Ct. Rep. 495, 36 I. Ed. 294; St. Louis etc. Co. v. Illinois (1902), 185 U. S. 203, 210, 22 Sup. Ct. Rep. 616, 46 I. Ed. 872; Buttfield v. Stranahan (1904), 192 U. S. 470, 24 Sup. Ct. Rep. 349, 48 L. Ed. 525; Union Bridge Co. v. U. S. (1907), 204 U. S. 364, 385, 27 Sup Ct. Rep. 367, 51 L. Ed. 523; U. S. v. Grimaud (1911), 220 U. S. 506, 31 Sup. Ct. Rep. 480, 55 L. Ed. 563; Red "C" Oil etc. Co. v. North Carolina (1912), 222 U. S. 380, 394, 32 Sup. Ct. Rep. 152, 56 I. E. d. 240; Interstate Commerce Commission v. Goodrich Transit Co. (1912), 224 U. S. 194, 214, 32 Sup. Ct. Rep. 436, 56 I. Ed. 729.

5 Buttfield v. Stranahan, supra, n. 4; Nicol v. Ames (1899), 173 U. S. 509, 514, 19 Sup. Ct. Rep. 522, 43 I. Ed. 786; U. S. v. Gettysburg etc. Railway Co. (1896), 106 U. S. 668, 680, 16 Sup. Ct. Rep. 427,40 I. Ed. 576; Hepburn v. Griswold (1869), 8 Wall. 603, 19 L. Ed. 513; Legal Tender Cases (1870), 12 Wall. 457, 20 I. Ed. 287.

6 Field v. Clark (1892), 143 U. S. 649, 694, 12 Sup. Ct. Rep. 495, 36 I. Ed. 294; Wayman v. Southard (1825), 10 Wheat. 1, 42, 43, 6. I. Ed. 253. 
tinction in mind, it can hardly be said that Congress has delegated to the Federal Reserve Board such power to make the law as involves a discretion as to what it shall be. The courts have repeatedly upheld the right of the legislative branch of a government, whether state or federal, to delegate to an administrative board "the power to determine some fact or state of things upon which the law makes or intends to make its own action depend."

The grant by the Federal Reserve Board to a national bank of a right to act as trustee, executor, etc., cannot be considered anything other than ministerial. It cannot possibly be considered either the enactment of a law or the declaration of what the law shall be. The words "authorized and einpowered" have frequently been construed as permitting no discretion as to what the law shall be but making the performance of the power or authority described, to be exercised under the law, mandatory, - a duty and obligation. $^{8}$

In view of the foregoing, every intendment being in support of the constitutionality of the provision, it is safe to conclude that there is very little, if any, ground for the contention that Section II (k) is an unconstitutional delegation of legislative authority.

The section should be construed as one in which the powers are conferred generally upon national banks; the exercise of these powers, however, to be limited to those national banks which apply therefor, provided a special permit be granted by the Federal Reserve Board pursuant to such application. The Federal Reserve Board is not vested with the power to confer the franchise but simply with the discretion to determine under what circumstances the powers-shall be exercised.

II.

Are the powers conferred upon national banks by Congress, through the administration of the Federal Reserve Board, authorized by the Constitution of the United States? It cannot be

7 State v. Kenosha E. Co. (1911), 145 Wis. 337, 347, 129 N. W. 600; State v. R. R. Commission (1908), 137 Wis. 80, 117 N. W. 846; Locke's Appeal (1873), $72 \mathrm{~Pa}$. St. 491, 498. See. cases reviewed in People v. Brady, supra, n. 1.

8 Veazie v. Inhabitants of China (1864), $50 \mathrm{Me}$. 518, 521; People v. Herkimer Co. (1867), 56 Barb. 452, 454; People v. Otsego Co. (1873), 51 N. Y. 401, 405; People v. Common Council (1892), 2 Misc. Rep. 7, 21 N. Y. Supp. 601, 603; Flynn v. Canton Co. (1874), 40 Md. 312, 319; Rankin v. Buckman (1881), 9 Ore. 253, 262; Bowen v. City of Minneapolis (1891), 47 Minn. 115, 116, 49 N. W. 683. 
questioned at this late date but that Congress has the unquestioned power to incorporate banking associations to be used as instrumentalities of the government in the conduct of its fiscal affairs. ${ }^{9}$

The next question which naturally suggests itself is whether it is essential that any special power vested in a national bank must be incidental or necessary to the conduct of the government's fiscal affairs, or whether it is sufficient if such power is, in the discretion of Congress, necessary and proper to the successful operation of the bank, as such.

If it be conceded that Congress has the power to create a - national bank it must naturally follow that Congress has the power to keep it in being. The United States Supreme Court has said: ${ }^{10}$ "The power to create carries with it the power to preserve. The latter is a corollary from the former."

The Supreme Court of the United States founded its opinion in the case of McCulloch v. Maryland, and those following it, upon the idea that the bank was "necessary and proper for carrying into effect the powers vested in the government of the United States;" and while the court in the Osborn ${ }^{11}$ case says that the bank is an instrument created "for national purposes only" it also says that:

"It is, undoubtedly, capable of transacting private as well as public business. While it is the great instrument by which the fiscal operations of the government are effected, it is also trading with individuals for its own advantage.

Later, the court says:

"The court has already stated its conviction, that without this capacity to trade with individuals, the bank would be a very defective instrument, when considered with a single view to its fitness for the purposes of government."

A review of the congressional legislation upon this subject discloses that, beginning with the first bank of the United States, organized in $179 r,{ }^{12}$ later, the second United States bank of $r 8 r 6^{13}$

${ }^{9}$ McCulloch v. Maryland (1819), 17 U. S. 316, 401, 4 L. Ed. 579; Osborn v. U. S. Bank (1824), 22 U. S. 738, 6 L. Ed. 204; Slaughterhouse Cases (1872), 83 U. S. 36, 64; Legal Tender Cases (1884), 110 U. S. 421, 445, 4 Sup. Ct. Rep. 122, 28 L. Ed. 204; Wilson v. Shaw (1906), 204 U. S. 24, 34, 27 Sup. Ct. Rep. 233, 51 L. Ed. 351; Veazie Bank v. Fenno (1869), 8 Wall., 533, 551, 19 L. Ed. 482; Eastern v. Iowa (1903), 188 U.S. 220, 229, 23 Sup. Ct. Rep. 294, 47 I. Ed. 452; Farmers' National Bank v. Dearing (1875), 91 U. S. 29,23 L. Ed. 196.

10 Farmers' National Bank v. Dearing, supra, n. 9.

11 (1824), 22 U. S. 737, 860, 6 I. Ed. 204.

121 Stats. at I. 192.

133 Stats. at L. 269. 
and lastly, the Act of June 3,1864 , the title of which was, in 1874 , changed to "The National Bank Act," every banking association organized has been endowed not only with powers by which the fiscal operations of the government have been sought to be effected, but as well with powers purely private in character, which latter powers have always been exercised for its own advantage in legitimate competition with other corporations of like character.

This dual endowment of powers has always been the subject of criticism urged against legislation of this character. It is now being urged that unless a trust busmess can be considered an essential part of the business of a bank performing public functions in aid of the federal government, no power can be said to have been conferred upon Congress by the Constitution to legislate concerning them; it is further said that trust companies are not instrumentalities of the federal government, that their functions are purely private ${ }^{44}$ and that they are therefore subject to the exclusive jurisdiction and control of the State. ${ }^{15}$

Those who offer this criticism overlook the fact that it is not essential that every special power vested in a national bank shall be incidental or necessary to the conduct of the government's fiscal affairs, but that it is sufficient if such power is, in the discretion of Congress, necessary to the successful operation of the bank.

The Supreme Court has said :16

"We think the sound construction of the constitution must allow to the national legislature that discretion, with respect to the means by which the powers it confers are to be carried into execution, which will enable that body to perform the high duties assigned to it, in the manner most beneficial to the people."

This discretion which is thus vested in our national legislature has been repeatedly recognized. ${ }^{17}$

Before proceeding, however, to a brief consideration of the question as to whether the powers specified in Section II (k)

14 Mercantile Bank v. N. Y. (1886), 121 U. S. 138; Jenkins v. Neff (1902), 186 U. S. 230,22 Sup. Ct. Rep. 905,46 I. Ed. 1140.

15 Pennoyer v. Neff (1877), 95 U. S. 714, 24 I. Ed. 565; Overby v. Gordon (1900), 177 U. S. 214, 20 Sup. Ct. Rep. 603, 44 L. Ed. 74; Brown v. Fletcher's Estate (1908), 210 U. S. 82, 89, 28 Sup. Ct. Rep. 702, 52 I. Ed. 966; U. S. V. Fox (1876), 94 U. S. 315, 24 I. Ed. 192; Mich. Trust Co. v. Ferry (1913), 228 U. S. 346, 33 Sup. Ct Rep. 550, 56 I. Ed. 857; 18 MeCulloch v. Maryland, supra, n. 9.

17 Osborn v. U. S. Bank, supra, n. 9; Legal Tender Cases, supra n. 9; Farmers' National Bank v. Dearing, supra, n. 9. 
constitute an unreasonable exercise of this discretion, it is perhaps advisable to dwell for a moment upon the distinction mentioned above concerning public and private powers. This distinction is very important since those who are now attacking Section II (k) and those who have attacked federal bank legislation have always assumed that every corporate power vested in a national bank must, in order to be valid, be one which is incidental to the performance of soine public function.

In discussing this question the Supreme Court has said :18

"The appellants endeavor to distinguish between this trade and its agency for the public, between its banking operations and those qualities which it possesses in common with every corporation, such as individuality, immortality, etc. While they seem to admit the right to preserve this corporate existence, they deny the right to protect it in its trade and business.

If there be anything in this distinction, it would tend to show, that so much of the act as incorporates the bank is constitutional, but so much of it as authorizes its banking operations is unconstitutional. Congress can make the inanimate body, and employ the machine as a depository of and vehicle for, the conveyance of the treasure of the nation, if it be capable of being so employed, but cannot breathe into it the vital spirit which alone can bring it into useful existence. Let this distinction be considered.

Why is it, that Congress can incorporate or create a bank? This question was answered in the case of $\mathrm{McCulloch} v$. The State of Maryland. It is an instrument which is 'necessary and proper' for carrying on the fiscal operations of government. Can this instrument, on any rational calculation, effect its object, unless it be endowed with that faculty of lending and dealing in money, which is conferred by its charter? If it can, if it be as competent to the purposes of government without, as with this faculty, there will be much difficulty in sustaining that essential part of the charter. If it cannot, then this faculty is necessary to the legitimate operations of government, and was constitutionally and rightfully engrafted on the institution. It is, in that view of the subject, the vital part of the corporation; it is its soul; and the right to preserve it originates in the same principle with the right to preserve the skeleton or body which it animates. The distinction between destroying what is denominated the corporate franchise, and destroying its vivifying principle, is precisely as incapable of being maintained as a distinction between the right to sentence

18 Osborn v. U. S. Bank, supra, n. 9, at p. 860. 
a human being to death and a right to sentence him to a total privation of sustenance during life. Deprive a bank of is trade and business; which is its sustenance, and its immortality, if it have that property, will be a very useless attribute."

Jational banks in their capacity as fiscal agents of the governrast are used as government depositaries. How can a national bank thrive upon the exercise of a naked function as a government depositary? One need not be a banker to recognize the fact that the business of being a government depositary involves at least so much expense as will cover the interest payable on such deposits to the government. Where will the bank obtain these expenses unless it is permitted to lend these funds "to private individuals? It is obvious that a national bank must derive its means of preservation from its banking operations conducted for its own advantage, as distimguished from its banking operations conducted as a fiscal agent of the government.

A national bank being an instrument or agency of the federal government in everything that it does as a bank, ${ }^{19}$ it follows that those things which tend to aid the national banks in their operations as banks, necessarily tend to aid the fiscal operations of the government.

The powers specified in Section II (k) are quite generally exercised by corporations which also exercise commercial banking powers and are similar in many respects to other corporate powers exercised by commercial banks, including national banks.

The business of the banks in the United States has become more and more intricate, during the last decade. The banks of to-day are becoming parties to transactions, legitimate in their character, which were unheard and unthought of fifty or one hundred years ago. It nay be conceded that at the time the national bank act was passed the right to act as trustee, executor, etc., was not regarded as a banking function; nor as incidental to any banking power.

It must be borne in nind that the selection of corporations to act in fiduciary capacities is of comparatively recent development. These corporations are popularly called trust companies. However recent that development may be, it may safely be said that, at the present time, it is almost as impossible for a trust company to

19 Osborn v. U. S. Bank, supra, n. 9. 
refrain from doing a banking business as it is for a banking corporation to refrain from doing a trust company business.

Prior to the passage of the Federal Reserve Act, national banks in several instances occupied the relation of trustee by operation of law as an incident to their banking business. ${ }^{20}$

Is it not true that the powers enumerated in Section II (k) of the Federal Reserve Act are more nearly incidental and more closely related to the business of banking than to that of any other class of corporations except those organized solely for the purpose of acting in fiduciary capacities? While it may be true that the naked functions of trustee, executor, administrator, etc., standing by themselves, are in their nature private, nevertheless it is suggested that these functions are not, by reason of that fact, foreign to or inconsistent with a general banking business.

Prior to the passage of the national bank act in I864, there were very few corporations in the various states of the United States possessing fiduciary powers. To-day the laws of every state in the United States authorize corporations to exercise certain trust powers and in forty-four of the forty-eight states, the laws permit a single corporation to exercise not only fiduciary powers but also commercial banking powers. The only states in which this cannot be accomplished are Michigan, Wisconsm, Pennsylvania and Nebraska.

In the forty-four states referred to above, state banks, and in some of them, even national banks, ${ }^{2 \pm}$ are expressly authorized by the state laws to do a trust business; in others, the state law provides for the formation of joint banks and trust companies, and in the majority of them the law expressly authorizes trust companies to do a general banking business. The result in all these cases is, however, a single corporation whether called a bank, a trust company, or a bank and trust company, possessing the powers to do both a commercial banking and a trust business.

20 American Can Co. v. Williams (1910), 178 Fed. 420; Boone Co. National Bank v. Latimer (1895), 67 Fed. 27, Richardson v. Olivier (1900), 105 Fed. 277; Richardson v. New Orleans Coffee Co. (1900), 102 Fed. 785; The Drovers' Nat'1 Bank v. O'Hare (1887), 119 Iil. 646, $10 \mathrm{~N}$. E. 360; Massey v. Fisher (1894), 62 Fed. 958; Montague v. Pacific Bank (1897), 81 Fed. 602.

${ }_{21}$ See R. \& B. Ann. Code, § 3346, (Wash.): "National Banks, having paid up capital of $\$ 50,000$ or more, when authorized or permitted so to do, by or under any act of the Congress of the United States, may exercise any of the powers conferred upon trust companies organized under this Act." 
The Supreme Court of the United States has said ${ }^{22}$ in distinguishing trust companies from banks that "trust conpanies are not organized primarily for banking purposes." Yet, more recently the Supreme Court recognized that trust companies were competitors of banks. ${ }^{23}$

It might well be admitted that trust companies are no more organized primarily for banking purposes than banks are organized primarily for the performance of trusts. If the laws of forty-four states out of the Union are to be considered imdices to the natural tendencies of corporations of this kind, then we must be convinced that the performance of trusts is as important an incident to the fiscal operations of banks as the doing of a banking business is an almost essential mcident to the activities of trust companies.

If, then, national banks are designed to perform functions similar to those possessed by state institutions with which they are in competition, then the special powers conferred on them by Section II (k) are no more than those powers now exercised by state banks in forty-four states in the United States. In view of this fact, can it be said that Congress exercised its discretion unreasonably in determining that the powers of national banks should be enlarged so that they might successfully compete with corporations organized or operating under state banking laws?

Unless those who attack the constitutionality of Section II (k) upon this ground can establish that Congress abused the discretion, admittedly vested in it, in determining that the powers conferred are essential to the successful operation of national banks, then their attack must fail. The Supreme Court of the State of Illinois in discussing this question, says: $:^{\dot{4}}$

"Since Congress has no express or implied power to create trust companies to act as trustees, executors, or administrators, the nature and character of their business making them the creatures of the various states, Congress could only vest national banking corporations with such powers if they were reasonably necessary to the efficiency of such corporations for the purposes of their creation as governmental agencies. If Congress had deemed the exercise

22 Jenkins v. Neff, supra, n. 14.

23 Amoskeag Savings Bank v. Purdy (1913), 231 U. S. 373, 391, 34 Sup. Ct. Rep. 114.

24 People v. Brady, supra, n. 1. 
of trust powers by national banks necessary to the accomplishment of the governmental purposes for which they were created, it would seem such power would have been granted expressly to all national banks, as was the power to exercise certain banking functions granted by section 5136 of the federal statutes. The right of a national bank to act as trustee, etc., as conferred by the Federal Reserve Act, was made elective with the bank. This feature of the Act would preclude the conclusion that Congress deemed it necessary, on any ground, that national banks possess the power to act as trustees, executors, administrators or registrars of stocks and bonds. If it had, it is evident it would not have made the act elective and permissive."

There is some force in the point made by the Illinois Supreme Court, but the court admits the right of Congress to vest national banking corporations with the powers in question if they are "reasonably necessary to the efficiency of such corporations for the purposes of their creation as governmental agencies." Whether or not they are reasonably necessary for that purpose is inore or less of a question of fact and has already been discussed above. The mere circumstance that these powers inay only be exercised by those banks who apply and receive permission therefor, cannot be considered such a fact as establishes presumptively that Congress did not consider them reasonably necessary for the successful operation of national banks.

If the courts are inclined to indulge in presumptions, they should rather presume that Congress considered these powers reasonably necessary to the efficiency of national banks as government agencies, for so long as every intendment is in support of the constitutionality of the act, only a clear repugnancy to the Constitution will destroy a presumption of constitutionality. ${ }^{25}$

\section{III.}

Will the exercise of these powers by national banks invade the exclusive jurisdiction and sovereignty of the states over persons and property within their territory? The government of the United States is one of limited powers and can claim no powers which are not granted to it by the Constitution. ${ }^{26}$ The

25 Buttfield v: Stranahan, supra, n. 4.

26 McCulloch v. Maryland, supra, n. 9; Martin v. Hunter's Lessee (1816), 14 U. S. 304, 4 I. Ed. 97; Gibbons v. Ogden (1824), 22 U. S. 1, 5 I. Ed. 302. 
powers of the United States government may be divided into four divisions: I. Those which belong exclusively to the states; 2. Those which belong exclusively to the national government; 3. Those which may be exercised concurrently and independently by both, and 4 . Those which may be exercised by the states, but only with the consent, express or implied, of Congress. Whenever the will of the nation intervenes exclusively in the fourth subdivision the authority of the state retires and lies in abeyance until a proper occasion for its exercise shall recur. ${ }^{27}$ The constitution of the United States provides ${ }^{28}$ that:

"The powers not delegated to. the United States by the constitution, nor prohibited by it to the states, are reserved to the states respectively, or to the people."

It is unquestionably well settled that a state has exclusive jurisdiction and authority over persons and property and over estates of deceased persons within its borders. ${ }^{29}$

Those who attack Section II (k) urge, from this premise, that the creation and management of trusts, the administration of estates of decedents, and the acting as registrar of stocks and bonds, are peculiarly state functions; that they relate solely to private personal and property rights and have nothing whatever to do with the affairs of the national government, and that for Congress to assume or attempt to control or regulate them is an invasion of the sovereignty of the state.

Conceding the correctness of these statements as established principles of law, it is difficult to note their application to the problem now under consideration. Prior to the adoption of the Federal Reserve Act, national banks exercised private powers without question. Can it be said that the private powers enumerated in Section II (k) invade the sovereignty of the states to

27 Farmers' and Mechanics' National Bank v. Dearing (1875), 91 U. S. $29,34,23$ I. Ed. 196.

28 U. S. Const. Amend. 10.

29 Pennoyer v. Neff (1877); 95 U. S. 714, 722, 24 L. Ed. 565; Overby v. Gordon (1900), 177 U. S. 214, 222, 27 Sup. Ct. Rep. 603, 44 L. Ed. 74; Brown v. Fletcher's Estate (1908), 210 U. S. 82, 89, 28 Sup. Ct. Rep. 702,50 L. Ed. $966 ;$ U. S. v. Fox (1876), 94 U. S. 315, 24 L. Ed. 192; Mich. Trust Co. v. Ferry (1913), 228 U.' S. 346, 33 Sup. Ct. Rep. 550, 56 I. Ed. 857; Yónley v. Lavender (1874), 88 U. S. 276, 22 L. Ed. 532; Union Bank v. Jolly's Administrators (1855), 18 How. 503, 15 L. Ed. 472; Security Trust Co. v. Black River Nat'l. Bank (1902), 187 U. S. 211, 23 Sup. Ct. Rep. 74, 47 L. Ed. 147; In re Servas' Estate (1915), 169 Cal. 240, 146. Pac. 651. 
any greater extent than the exercise of any of the other private powers of a national bank?

The Federal Reserve Act does not make it mandatory that a national bank act as trustee, administrator, executor or registrar. It merely gives a national bank a right to exercise such powers when selected by those who are interested in the selection. A trustee under a deed of trust or mortgage is usually agreed upon by the parties to the indenture. An executor or trustee under a will is designated by the testator. A registrar of stocks and bonds owes his appointment to the executive branch of a corporation. An administrator is appointed from among those qualified to act by a court having jurisdiction over the probating of the estate of the decedent.

How does the exercise of any of these capacities at the instance of the parties in interest take out of the control of the state, property within its borders? If it is to be construed as such, then the taking of a deposit by a national bank from a resident of a state who selects it as his depositary must likewise be construed as a federal interference with state control over property within its territorial limits.

National banks, as instrumentalities of the federal government, created for a public purpose, are necessarily subject to the paramount authority of the United States. ${ }^{30}$

Nevertheless national banks are subject also to the laws of the state. For jurisdictional purposes, for instance, a national bank is a citizen of the state in which it is located. ${ }^{31}$

It may receive interest on its loans at the rate allowed by the laws of the state where the bank is located. ${ }^{32}$ The states may tax the capital stock of the national banks as the personal property of its several owners. ${ }^{33}$ In certain cases, the state courts are given jurisdiction over national banks. ${ }^{34}$

It may well be said that national banks are governed in their daily course of business far more by the laws of the state than

30 Davis v. Elmira Savings Bank .(1896)), 161 U. S. 275, 16 Sup. Ct. Rep. 502, 40 I. Ed. 700; McClellan v. Chipman (1896), 164 U. S. 347, 357, 17 Sup. Ct. Rep. 85, 41 L. Ed. 461; Easton v. Iowa (1903), 188 U. S. 220, 237, 23 Sup. Ct. Rep. 294, 47 I.. Ed. 452; Christopher v. Norvell (1906), 201 U. S. 216, 26 Sup. Ct. Rep. 502, 50 L. Ed. 732.

${ }^{31}$ Hazen v. I Iyndonville Nat'l. Bank (1898), 70 Vt. 543, 41 Atl. 1046; Davis v. Cook (1874), 9 Nev. 134.

${ }_{32}$ U. S. Rev. Stats. \$5197.

38 U. S. Rev. Stats. \$5219.

s4 U. S. Rev. Stats. \$5198, 22 Stats. at I. \$163, 25 Stats. at I. \$436. 
of the nation. All their contracts are governed and construed. by state laws. Their acquisition or transfer of property, their right to collect their claims and their liability to be sued for debts are all based on state law. It is only when the state laws incapacitate the banks from discharging their duties to the government that they do not apply. ${ }^{35}$

The Federal Reserve Act does not attempt to interfere with the jurisdiction of the courts designated by the several states to administer estates of decedents or to carry out trusts, and the right of the states to control these matters is not only not invaded but the act specifically provides that these capacities may only be exercised by national banks "when not in contravention of state or local law:"

It is maintained that this limitation in the grant of these powers was not necessary in order to make this provision constitutional. The fact, however, that the state laws are determinative of the question as to whether or not the powers of executor, etc., shall be exercised, shows that Congress has studiousiy avoided the invasion of such rights as it is claimed are reserved to the states.

IV.

How should the term "when not in contravention of state or local law" be construed? The laws of each state in the Union in which an attempt may be made by a national bank doing business therein to exercise the capacities in question must be examined separately in order to determine whether the exercise of these capacities contravenes the law of that particnlar state.

If, of course, the state laws are silent on the subject, then there is no law to contravene, and the federal law is supreme. If a state has enacted legislation either expressly permitting national banks to act in these capacities ${ }^{36}$ or has imposed only such qualifications upon corporations seeking to act in these capacities as a national bank may be able to comply with, without being inconsistent with or contrary to any of the provisions of the National Bank Act or Federal Reserve Act, then also there is no law to contravene.

35 McClellan v. Chipman, supra, n. 28.

36 R. \& B. Ann. Code, \$3346 (Wash.) 
It is here advisable to bear in mind the distinction between a positive grant of power and the permission or right to exercise a power granted by some one else. It is obviously impossible for a state to grant to or confer upon national banks any rights or powers not granted or conferred upon them by Congress.

It is not contended that if the states of the Union would authorize national banks to act in these capacities, they could do so in the absence of some provision in the federal law permitting them to do so. But Congress having given national banks the power to act in these capacities, provided it be not in contravention of state or local law, the states can permit this to be accoinplished by either appropriate legislation or by legislative silence, and thereby avoid the contravention of a state or local law.

The several states in the Union have different provisions as to the qualifications necessary for and as to who inay be executors, administrators or trustees, excluding some and preferring others. It is not impossible to conceive of legislation wherein the qualifications necessary for the exercise of these capacities would permit national banks to exercise them.

It was suggested by the Supreine Court of the State of Illinois $^{37}$ that where banking corporations doing business in the State of Illinois, qualifying under the trust act to accept and execute trusts, are subject to the visitorial and regulatory powers of the state, that it would be in contravention of the laws of the State of Illinois to permit a national bank doing business in that state to exercise these capacities, unless it were at the same time admitted that the State of Illinois had visitorial and regulatory powers over the national banks engaging in the execution of trust powers.

The court points out that the question has been settled against the right of the state to regulate or control any department of a national bank, even assuming that Congress had the power to confer upon it the authority to act as trustee, executor or administrator.

It does not seem unreasonable to conclude that if a national bank can act as a.trustee, executor, administrator, etc., in a state only upon condition that it submit itself to examination and possibly regulation and restrictions by state officials, it must be|

37 People v. Brady, supra, n. 1. 
said to be in contravention of the state or local law for a national bank to act in said capacities, and it would be the duty of the Federal Reserve Board to deny any applications made by a national bank doing business in that state to act in said capacities.

In order to make it possible for a national bank to exercise these rights in a state, not only must the state permit it in the manner outlined above, but it must also waive such rights as to national banks as it may have in reference to other corporations exercising the same capacities, and, in general, any interference which would tend to frustrate the purposes of Congress or impair the efficiency of the banks to discharge the duties imposed upon them by the laws of the United States.

It is, of course, not claimed that a national bank acting as a trustee, executor or administrator, could not be subjected to an examination in reference to the particular trust or estate which was being administered upon by it, in the state courts of the state im which it was doing business or performing the trust.

In this regard the saine rule would apply as applies to national banks in their daily course of business, and it has already been pointed out that national banks are subject to the laws of the state in which they do business and are governed in their daily course of business far more by the laws of the state than those of the nation.

An application was recently made in New Hampshire ${ }^{38}$ for the appointment of a national bank doing business in the City of Concord as the administrator of the estate of a decedent. The' laws of the State of New Hampshire provided that:

"No trust company, loan and trust company, loan and banking company, bank or banking company, or similar corporation, shall hereafter be appointed administrator of an estate, executor under a will or guardian or conservator of the person or property of another."39

It appeared that the national bank whose appointment was being sought as administrator had been authorized and empowered by the Federal Reserve Board by a special permit to act in said capacity. It was urged that the exercise of the power of administrator would not be in contravention of the local law of the State of New Hampshire in that the act heremabove referred to

${ }^{38}$ Appeal of Woodbury (N. H., December 7, 1915), 96 Atl. 299.

39 Statutes, New Hampshire, 1915, c. 109, Sec. 34. 
applied to state banks only. In the course of its opinion, the court said:

"The state has the power to prohibit the probate courts from appointing banks as administrators. * * * That the prohibition was intended to apply generally to banks and trust companies is not open to serious doubt. The statute does not attempt to manage or regulate the business of national banks located within the state in contravention of the laws of the United States (citing cases), but it merely prohibits the probate courts from appointing them to act as administrators, executors or guardians. Moreover, the Federal Reserve Act recognizes the right of the state to prevent banks from acting in those capacities and grants them the power to do so only 'when not in contravention of state or local law.' As the exercise of such powers is in contravention of our statute the appointment of the bank would be illegal."

It is clear that under the laws of the State of New Hampshire no banks of any character could qualify to act as the administrator of an estate, executor under a will, or guardian of the person or property of another. The propriety of the ruling of the Supreme Court of the State of New Hampshire can therefore not be denied in giving effect to Section II (k) of the Federal Reserve Act in connection with the laws of the State of New Hampshire.

An effective discussion of this question would necessarily be divided into forty-eight subdivisions, each subdivision being confined to a consideration of the laws of each of the states in the United States. It is sufficient to say that the term "when not in contravention of any state or local law," must receive individual and separate construction in reference to each application for permission to exercise the capacities under consideration and nust be considered separately, based upon the status of the law as it then exists, in the state in which the national bank is doing business.

San Francisco, California.

Nat Schmulozwitz. 